https://doi.org/10.48009/1_iis_2014_88-97

Issues in Information Systems

Volume 15, Issue I, pp. 88-97, 2014

\title{
EXPERIENTIAL LEARNING TO MAKE INFORMATION SYSTEMS PROGRAMS MORE RESPONSIVE TO STUDENT AND INDUSTRY NEEDS
}

\author{
Arnaldo I. Ramos-Torres, University of Puerto Rico, arnaldo.ramos1@upr.edu
}

\begin{abstract}
Information Systems (IS) programs are facing serious challenges. Some of them are external, therefore we can mostly react to them, while others are internal to our programs and consequently we can do a lot about them. Among the internal ones, we have the need to develop a wider set of skills in our graduates, ranging from functional knowledge to technical skills, without leaving out "soft skills". We also need to change the educational strategies we have used for decades, reducing the emphasis on lecture and exercises and increasing the use of experiential learning models.

Our contention is that an experiential learning model, like Project-Based Learning (PBL), when used as an educational and assessment strategy, makes an IS program more responsive to both student and industry needs, and also improve stakeholders' perception about the program.
\end{abstract}

Keywords: Information systems (IS), IS challenges, Experiential learning, Project-based learning (PBL), Studentoutcomes, Industry needs

\section{INTRODUCTION}

Information Systems (IS) programs are facing challenges so serious that they are threatening the future of IS as an academic discipline. It is very important for IS academics to be aware of these challenges, the implications they have, and the strategies that can be implemented to address them.

This paper is the second of a trilogy on how to address the challenges currently faced by Information System programs. It presents empirical research on how Project-Based Learning (PBL) has been implemented in our Computer Information Systems program, including the research methodology, and the results obtained, as well as the conclusions and best practices derived from these results. But first, we will briefly review the context of this research through the following background section.

\section{BACKGROUND}

\section{IS program challenges}

In a previous paper [14], we discussed the main challenges faced by IS programs, identified two strategies to deal with these challenges, and described an implementation methodology for each strategy. Its main purpose was to contextualize further research that we present in this and another paper. The two main challenges discussed in that paper were enrollment reduction, and loss of relevance of IS programs. Other challenges were also discussed, and classified in the following three categories: (1) industry trend, (2) perception-related, and (3) internal challenges. We recommended focusing on internal challenges, because they are the ones over which we have the highest level of control, and also because they represent a good opportunity to influence other types of challenges, particularly those related to perception. 
A proposal to address internal challenges: redefine educational strategies and skill set in IS programs

To tackle internal challenges, we specifically proposed two strategies: (1) To offer a functionally integrated curriculum and deliver it through an experiential educational strategy, like Project Based Learning, and (2) To continuously analyze the skill set that we are developing in our students around the specific market that we want to serve, and redefine this set accordingly.

Since PBL can be implemented regardless of the set of skills being emphasized by the particular IS program, we will address the first strategy in this paper and leave the second one for a separate paper.

\section{Experiential learning and PBL}

Experiential learning can be defined as "education that occurs as a direct participation in the events of life" [11]. It involves a "direct encounter with the phenomena being studied rather than simply thinking about the encounter, or only considering the possibility of doing something about it." [4] Students learn by experiencing rather than simply listening. Case studies based on real or simulated, but meaningful, situations, as well as team projects and industry interaction are ways for implementing this kind of learning [7].

Project-Based Learning is an experiential learning model implemented through the preparation of comprehensive and meaningful projects. It promotes collaborative versus isolated learning, active (hands on) versus passive learning and integrated versus fragmented learning. It emphasizes applied versus theoretical learning, high-order thinking versus plain comprehension, and a wide range of skills, including technical, managerial and soft skills. [1, $3,13]$.

Our contention is that an experiential learning model, like Project-Based Learning (PBL), when used as an educational and assessment strategy, makes an IS program more responsive to both student and industry needs, and also improve stakeholders' perception about the program. The way we implement this strategy deserves close attention, as it can greatly influence its effectiveness. We propose to formally embed projects into curricular design and to properly align them to student outcomes, so as to get the most benefits.

\section{A PBL IMPLEMENTATION: THE UPR CASE}

At our Computer Information Systems program we have used some form of Project-Based Learning (PBL) for a long time, but in the last several years we have formally embedded this strategy into a new curricular design. As an educational strategy, it has enabled the achievement of our student outcomes in an interesting and practical way, while as an assessment strategy it has allowed measuring outcome attainment as a byproduct of the enabling process.

\section{Implementation methodology}

To implement PBL, we first created an Assessment Committee consisting of several faculty members. The committee used the five-step methodology in Table 1. It assumed ultimate responsibility for all steps, but delegated some of them to the professors in charge of the courses.

\begin{tabular}{|l|l|}
\hline \multicolumn{2}{|c|}{ Table 1: Methodology used to implement PBL } \\
\hline$\#$ & Steps \\
\hline 1 & Identifying typical IS projects \\
\hline 2 & Embedding projects into the curriculum \\
\hline 3 & Creating cases and/or situations related to the projects \\
\hline 4 & Assessing the attainment of student outcomes through the projects \\
\hline 5 & Controlling quality of the process \\
\hline
\end{tabular}

Let's take a closer look at what we did in each one of the steps, as well as how we did it. 
1. Identifying typical IS projects. We identified typical projects performed by IS professionals. Our industry experience was very helpful in completing this step. We also got input from employers, alumni and our Advisory Board. Table 2 briefly describes these projects.

\begin{tabular}{|c|c|c|}
\hline$\#$ & roiect title & ble 2: Examples of IS projects prepared by students \\
\hline 1 & $\begin{array}{l}\text { Design a technological } \\
\text { infrastructure to implement an } \\
\text { application }\end{array}$ & $\begin{array}{l}\text { Students design an infrastructure with the typical hardware and } \\
\text { software components needed to properly operate a system in } \\
\text { an organization, and prepare specifications for each } \\
\text { component. }\end{array}$ \\
\hline 2 & $\begin{array}{l}\text { Define requirements and } \\
\text { prepare a logical design for an } \\
\text { application }\end{array}$ & $\begin{array}{l}\text { Students analyze an existing business operation and prepare } \\
\text { the requirements for a system that can support this operation. } \\
\text { The requirements defined, taken as a whole, must define a new } \\
\text { way to operate. }\end{array}$ \\
\hline 3 & $\begin{array}{l}\text { Prepare a project management } \\
\text { plan to implement a system }\end{array}$ & $\begin{array}{l}\text { Students prepare a plan to implement a system, consisting of } \\
\text { the different tasks that define the scope of the project, the } \\
\text { dependencies between these tasks, the time estimates for the } \\
\text { tasks and the resources needed to perform them. Students also } \\
\text { address administrative aspects like the project organization, the } \\
\text { evaluation of risks, and the procurement of the resources } \\
\text { needed. }\end{array}$ \\
\hline 4 & $\begin{array}{l}\text { Prepare a physical design and } \\
\text { implement a web based } \\
\text { application }\end{array}$ & $\begin{array}{l}\text { Students design the components of a web application, } \\
\text { including the database, the user interface and the business } \\
\text { rules, based on a set of functional requirements. They actually } \\
\text { implement the application by creating the database, the screens } \\
\text { and the reports, and by preparing the code to implement the } \\
\text { business rules. }\end{array}$ \\
\hline 5 & $\begin{array}{l}\text { Configure and implement an } \\
\text { E-Business application }\end{array}$ & $\begin{array}{l}\text { Students configure an E-Business software to support the } \\
\text { operation of a wholesale firm or a retail store. Among other } \\
\text { things, they define the product catalog, and the user interface, } \\
\text { as well as the policies and procedures for the revenue cycle. }\end{array}$ \\
\hline 6 & $\begin{array}{l}\text { Prepare a disaster recovery } \\
\text { plan for a data center }\end{array}$ & $\begin{array}{l}\text { Students prepare a disaster recovery plan for an IS department. } \\
\text { They document all the available resources, including hardware, } \\
\text { software, applications, databases, and physical facilities. They } \\
\text { also identify major risks, and define both preventive as well as } \\
\text { recovery measures. }\end{array}$ \\
\hline 7 & $\begin{array}{l}\text { Prepare a physical design and } \\
\text { implement a database } \\
\text { application }\end{array}$ & $\begin{array}{l}\text { Students design the components of an application using the } \\
\text { facilities provided by a data base management system. } \\
\text { Database design, data security, as well as backup and recovery } \\
\text { are emphasized. }\end{array}$ \\
\hline 8 & $\begin{array}{l}\text { Prepare a data warehouse to } \\
\text { support decision making }\end{array}$ & $\begin{array}{l}\text { Students define the requirements for a Business Intelligence } \\
\text { application and implement a data warehouse to support it. }\end{array}$ \\
\hline 9 & $\begin{array}{l}\text { Design a wide area network to } \\
\text { support the operation of an } \\
\text { information system }\end{array}$ & $\begin{array}{l}\text { Students design an enterprise wide area network with the } \\
\text { typical hardware, software and communication lines needed to } \\
\text { properly operate a system in an organization. }\end{array}$ \\
\hline 10 & $\begin{array}{l}\text { Design a local area network to } \\
\text { support the operation of an } \\
\text { information system }\end{array}$ & $\begin{array}{l}\text { Students design an enterprise local area network with the } \\
\text { typical hardware, software and communications equipment } \\
\text { needed to properly operate a system in an organization. }\end{array}$ \\
\hline
\end{tabular}

2. Embedding projects into the curriculum. We embedded the previously identified projects into our curriculum by assigning to each course a project where students had the opportunity to integrate the knowledge acquired and to develop the required skills. We also aligned the projects with the student outcomes $^{1}$. When necessary, we created new courses to accommodate projects. We established a "many-to-many" relationship between projects and student outcomes. That is, an outcome could be 


\section{Issues in Information Systems \\ Volume 15, Issue I, pp. 88-97, 2014}

supported by more than one project and a project could support more than one outcome. Table 3 presents the mapping between projects, student outcomes and courses in our IS program.

\begin{tabular}{|l|l|l|l|}
\hline \multicolumn{3}{|c|}{ Table 3: Mapping between projects, student outcomes and courses } \\
(only some examples)
\end{tabular}

3. Creating cases or situations related to the projects. We created cases or situations upon which the projects are developed. We put a lot of attention to make sure the projects resulting from these cases or situations were comprehensive and meaningful enough to allow students to apply most knowledge obtained and skills developed in the course, but at the same time manageable enough for a one semester course. The professors prepared the cases and project descriptions, and the Assessment Committee reviewed and approved them.

4. Assessing student outcomes through the project. We assessed student projects to determine the extent to which student work attained the student outcomes supported by the project. The professors in charge of the courses performed the assessment, using standard rubrics prepared by the Assessment Committee. 


\section{Issues in Information Systems \\ Volume 15, Issue I, pp. 88-97, 2014}

5. Controlling quality of the whole process. The Committee controlled quality throughout all steps by several means. One of them was requiring students to make oral presentations to the professor. Other quality control measures were the use of a standard rubric for each project and the use of an automated tool to facilitate data collection and calculations. The Assessment Committee prepared the rubrics, as well as the data collection tool. It also encouraged students to prepare project portfolios and to participate in poster sessions.

\section{RESEARCH METHODOLOGY, RESULTS AND DISCUSSION}

\section{PBL as an educational strategy}

Research methodology. Regarding the use of PBL as an educational strategy, we have surveyed students every year for the last three years. In order to avoid sampling the same student more than once, or skipping any student, we administer the surveys in a senior level course that is offered once a year and required to all students. The professor instructs students to answer the survey based on the projects prepared in all courses already taken. We use an anonymous questionnaire with the following three-point scale: Do not agree, Partially agree, Agree. Questionnaire was originally pilottested to make sure it was clearly understood by students. We have surveyed twenty five, seventeen, and sixteen students respectively in November 2011, 2012 and 2013.

Results. Table 4 contains student survey results.

\begin{tabular}{|c|c|c|c|}
\hline \multicolumn{4}{|c|}{ Table 4: PBL student survey results } \\
\hline \multirow{2}{*}{$\begin{array}{l}\text { Statement on the use of PBL as an } \\
\text { educational strategy }\end{array}$} & \multicolumn{3}{|c|}{ Percentage of students answering "Agree" } \\
\hline & Nov 2011 & Nov 2012 & Nov 2013 \\
\hline a. Learning process is more fun & $60 \%$ & $47 \%$ & $76 \%$ \\
\hline b. Class is more interesting & $84 \%$ & $71 \%$ & $76 \%$ \\
\hline c. Facilitates understanding concepts & $84 \%$ & $71 \%$ & $71 \%$ \\
\hline $\begin{array}{ll}\text { d. } & \text { Both theory and practice are } \\
\text { learned }\end{array}$ & $84 \%$ & $82 \%$ & $76 \%$ \\
\hline e. Higher grades are obtained & $40 \%$ & $41 \%$ & $41 \%$ \\
\hline f. Helps to retain what is learned & $88 \%$ & $82 \%$ & $82 \%$ \\
\hline $\begin{array}{ll}\text { g. } & \text { Encourages learning }\end{array}$ & $84 \%$ & $71 \%$ & $76 \%$ \\
\hline h. Motivates creativity & $92 \%$ & $94 \%$ & $82 \%$ \\
\hline i. Motivates to explore new concepts & $92 \%$ & $65 \%$ & $76 \%$ \\
\hline j. $\quad$ Motivates high order thinking & $88 \%$ & $76 \%$ & $76 \%$ \\
\hline k. Helps knowledge integration & $96 \%$ & $94 \%$ & $88 \%$ \\
\hline $\begin{array}{ll}\text { 1. Helps to develop problem solving } \\
\text { skills }\end{array}$ & $100 \%$ & $88 \%$ & $88 \%$ \\
\hline m. Helps to develop teamwork skills & $72 \%$ & $53 \%$ & $76 \%$ \\
\hline Total students surveyed & 25 & 17 & 16 \\
\hline
\end{tabular}

Discussion of results. As can be seen from the previous table, the level of agreement with most statements included in the survey is very high. Some statements require special attention for the high level of agreement they obtained. For example, "Both theory and practice are learned", "Helps to retain what is learned", "Motivates creativity", "Helps knowledge integration", and "Helps to develop problem solving skills".

One interesting point is that the statement "Higher grades are obtained" got a relatively low percentage of agreement from students, evidencing that although it is not easier for them to get higher grades through PBL compared to other methods, they recognize the value of PBL as an educational strategy. 


\section{Issues in Information Systems \\ Volume 15, Issue I, pp. 88-97, 2014}

Even though the percentages obtained by the different statements were mostly consistent between the three surveys, there were some variations that are worth mentioning. One of them is in the first statement ("Learning process is more fun"), where the percentage of students fully agreeing with the statement changed from $60 \%$ to $47 \%$, and then to $76 \%$. Another is in statement "i" ("Motivates to explore new concepts"), where the percentage of students fully agreeing with the statement changed from $92 \%$ to $65 \%$, and then to $76 \%$. Finally, another variation occurred in statement "m" ("Helps to develop teamwork skills"), where the percentage of students fully agreeing with the statement changed from $72 \%$ to $53 \%$, and then to $76 \%$. These variations will be closely watched next time we conduct the survey to determine if they were incidental or if they constitute some kind of pattern.

One point that deserves emphasis is that in all survey instances several students recommended through written remarks that projects be assigned by parts, starting early in the semester, and that feedback on the individually delivered parts be provided before integrating them into a full final project.

\section{PBL as an assessment strategy}

Research methodology. Regarding the use of PBL as an assessment strategy, we have formally assessed the attainment of student outcomes in our program for eight semesters, from August 2009 to January 2013. The main assessment method has been the appraisal of student performance ${ }^{3}$ through the preparation of course embedded projects closely resembling those performed by IS professionals. Assessment is performed every semester and all our students participate in the process as they go through the different courses. Analytic task-specific rubrics ${ }^{4}$ were prepared and approved by the Assessment Committee for each project, in order to guide, standardize and control the quality of the process. We performed a pilot assessment in the January 2009 semester to validate rubrics. We used an automated tool to facilitate data collection and calculations, as well as to improve quality in the process.

Results. In Table 5 we present assessment results for the ten student outcomes of our IS program along eight semesters. When more than one method supported a given outcome, we calculated an overall attainment rate adding the number of students attaining the outcome in each method and dividing by the total number of students sampled by these methods. 


\begin{tabular}{|c|c|c|c|c|c|c|c|c|}
\hline \multicolumn{9}{|c|}{ Table 5: Student outcome attainment results } \\
\hline \multirow[b]{2}{*}{ Student Outcome } & \multicolumn{8}{|c|}{ Percentage of attainment } \\
\hline & $\begin{array}{l}\text { Aug } \\
2009\end{array}$ & $\begin{array}{c}\text { Jan } \\
2010\end{array}$ & $\begin{array}{l}\text { Aug } \\
2010\end{array}$ & $\begin{array}{ll}\text { Jan } \\
2011\end{array}$ & $\begin{array}{l}\text { Aug } \\
2011\end{array}$ & $\begin{array}{c}\text { Jan } \\
2012\end{array}$ & $\begin{array}{l}\text { Aug } \\
2012\end{array}$ & $\begin{array}{c}\text { Jan } \\
2013\end{array}$ \\
\hline $\begin{array}{l}\text { 1. To analyze an operation } \\
\text { within an organization, } \\
\text { identify problems and make } \\
\text { recommendations to solve } \\
\text { these problems. }\end{array}$ & 100.0 & 100.0 & 100.0 & 100.0 & 100.0 & 93.75 & 95.65 & 100.0 \\
\hline $\begin{array}{l}\text { 2. To select or design a system } \\
\text { to solve the problems } \\
\text { identified in an operation. }\end{array}$ & 36.36 & 64.29 & 92.86 & 91.15 & 96.43 & 100.0 & 94.74 & 100.0 \\
\hline $\begin{array}{l}\text { 3. To plan and supervise the } \\
\text { implementation of a system } \\
\text { that solves the problems } \\
\text { identified in an operation. }\end{array}$ & N/A & 100.0 & N/A & 100.0 & 100.0 & 96.30 & 95.24 & 85.71 \\
\hline $\begin{array}{l}\text { 4o use current techniques, } \\
\text { skills, tools and best practices } \\
\text { to design, implement and } \\
\text { manage information systems. }\end{array}$ & 98.22 & 100.0 & 82.95 & 88.69 & 94.23 & 91.94 & 91.14 & 86.49 \\
\hline $\begin{array}{l}\text { 5. To understand the impact that } \\
\text { organizational, local and } \\
\text { global environments have in } \\
\text { the implementation and } \\
\text { management of information } \\
\text { systems. }\end{array}$ & 85.72 & 100.0 & 100.0 & 95.42 & 95.24 & 96.49 & 95.56 & 94.74 \\
\hline $\begin{array}{l}\text { 6. To value the protection of } \\
\text { information system resources } \\
\text { in an organization, and to } \\
\text { identify ways in which this } \\
\text { protection can be achieved. }\end{array}$ & $\mathrm{N} / \mathrm{A}$ & 75.00 & $\mathrm{~N} / \mathrm{A}$ & 94.44 & 100.0 & 96.30 & 90.91 & 100.0 \\
\hline $\begin{array}{l}\text { To be aware of the high level } \\
\text { of change in the Information } \\
\text { Systems field, and the need to } \\
\text { use different mechanisms to } \\
\text { update his knowledge. }\end{array}$ & $\mathrm{N} / \mathrm{A}$ & 85.72 & 100.0 & 93.75 & 100.0 & 96.77 & 86.21 & 92.86 \\
\hline $\begin{array}{l}\text { 8. To recognize the importance } \\
\text { of ethical values and } \\
\text { interpersonal relationships in } \\
\text { an information systems } \\
\text { professional. }\end{array}$ & 100.0 & 100.0 & 80.30 & 73.33 & 75.00 & 70.59 & 94.12 & 100.0 \\
\hline $\begin{array}{l}\text { 9. To communicate effectively } \\
\text { with a range of audiences. }\end{array}$ & 100.0 & 99.13 & 100.0 & 86.11 & 96.30 & 70.49 & 82.54 & 90.62 \\
\hline $\begin{array}{l}\text { 10. To function effectively in } \\
\text { teams seeking to accomplish } \\
\text { a common goal. }\end{array}$ & N/A & 77.78 & 83.33 & 100.0 & 94.12 & 95.45 & 78.57 & 100.0 \\
\hline
\end{tabular}

Discussion of results. As can be seen from the previous table, the level of attainment was very high in most of the outcomes. But even though, some cases deserve particular comments.

a. The attainment rate for outcome \#2 ("To select or design a system to solve the problems identified in an operation") started as low as 36.36 in the first semester, went up to 64.29 next semester and above 90 in subsequent semesters. These improvements showed up after the professor implemented corrective actions, like assigning the project earlier in the course, assigning the 


\section{Issues in Information Systems \\ Volume 15, Issue I, pp. 88-97, 2014}

project by parts, and providing feedback about each part before integrating them into one full project.

b. The attainment rate for outcome \#8 ("To recognize the importance of ethical values and interpersonal relationships in an information systems professional.") started in 100 in the first two semesters, went down for about three semesters, and then it went up again.

c. The attainment rate for outcome \#9 ("To communicate effectively with a range of audiences.") dropped to 70.49 in one semester, but recovered in the last two semesters.

\section{CONCLUSIONS}

Results evidence the successful use of Project-Based Learning (PBL) in our program both to enable and to assess student outcomes. For several years, our students have expressed their preference and support for the use of PBL as an educational strategy, and they have consistently produced very high outcome attainment percentages.

Results also support our contention that an experiential learning model, like Project-Based Learning (PBL), can make IS programs more responsive to both student and industry needs, and also improve stakeholders' perception about the program.

- The percentages obtained in the student survey demonstrate our students' preference and support for PBL as an educational strategy, which in turn supports its capability to make IS programs more responsive to student needs.

- The assessment results demonstrate our students' capability to prepare projects closely resembling those performed by industry practitioners, which in turn supports the capability of PBL to make IS programs more responsive to industry needs.

- A reasonable inference can be made that, through increasing our program's responsiveness to both student and industry needs, PBL has also improved stakeholders' perception about our program and the IS profession. Even so, more research is needed to conclude this, and if so, to determine the extent of this improvement compared to other factors.

We encourage readers to implement the PBL strategy in their programs, following the implementation and the research methodologies that we have used, and to assess students' receptiveness towards PBL, its impact on the attainment of student outcomes, and its influence on the perception-related challenges faced by these programs.

\section{BEST PRACTICES}

The way we implement PBL can greatly influence its effectiveness. Projects should be formally embedded into curricular design and properly aligned to student outcomes, so as to get the most benefits. They should not be an optional, non-standard or complementary educational strategy in the program. Currently used projects must be carefully reviewed to make sure they are suitable to enable and assess student outcomes, before adopting them.

An implementation approach planned, coordinated and directed by a group of faculty members will be better accepted, and will produce more benefits, than an approach completely conducted by faculty management.

The way projects are designed is also very important. Projects should closely resemble those prepared by IS practitioners, so that students can obtain the higher benefits. Stakeholders must participate in project identification and design. Projects must be comprehensive and meaningful enough to allow students to apply knowledge obtained and skills developed in the course, but at the same time they must be manageable enough for a one semester course. Faculty should avoid "teaching just enough for the project" and students should avoid "learning just enough to do 


\section{Issues in Information Systems \\ Volume 15, Issue I, pp. 88-97, 2014}

the project", although the negative effects of doing this will be attenuated to the extent that comprehensive and meaningful projects are used.

Each project must contain carefully defined instructions for students. If the level of detail and structuring in the instructions is high, the probability of getting meaningful results in a one semester course increases (which could be encouraging), but students may then lose the benefits of dealing with uncertainty or mistakes. On the other hand, if the level of detail and structuring is low, students may have to dedicate a long time to find their way and get through the project (which could be frustrating), but additional benefits may be obtained. Structuring could be lower for projects emphasizing problem analysis and solution definition, and higher for projects involving solution design and implementation.

Quality control is a major consideration. Quality should be exercised across the whole process, with emphasis in the proper definition of the projects, the use of standard rubrics, and the use of a tool for data collection and calculations. In our case, a very effective quality control measure was to require students to make oral presentations to the professor. Although presentations take time, they allow the professor to more effectively assess the quality of the project, to validate the real level of understanding of each student, and to assess individual contributions in group projects. Presentations also allow the professor to assess "soft skills", like communication, teamwork and interpersonal relationships.

Professors should assign projects by parts starting early in the semester, and provide feedback on the individual parts before asking students to integrate them into a full project. This way, besides having more time to prepare the project, students will benefit from the feedback, and final projects will be more complete and refined.

Faculty management, as well as faculty members, must encourage students to prepare an integrated project portfolio evidencing their performance throughout the whole program, which can be used both for assessment and for job seeking purposes. Students can present their projects in poster sessions, where potential employers are invited to attend. To the extent that IS students' performance is widely and consistently communicated to employers, their perception on these programs should improve.

\section{ACKNOWLEDGEMENTS}

The author wants to acknowledge the support from his colleagues in the IS Department, particularly those belonging to the Assessment Committee. A special acknowledgement and appreciation to Dr. Pedro Rodríguez-Esquerdo, IS Department head, and Prof. María del Rosario Rodríguez-Orellana, IS major coordinator, for reviewing the draft of this paper and making thorough recommendations to improve it.

\section{ENDNOTES}

1 Student outcomes refer to what students are expected to know and be able to do by the time of graduation.

2 There is a "many to many" relationship between projects and student outcomes. A given project can support more than one student outcome and a student outcome can be supported by more than one project.

Performance appraisal is a direct assessment method in which the student evidences his knowledge, skills and attitudes through the preparation of specific products.

4 An analytic rubric collects information about individual student performance and a task specific rubric is oriented towards the assessment of a particular task. 


\section{REFERENCES}

1. Abraham, Thomas; Beath, Cynthia; Bullen, Christine; Gallagher, Kevin; Goles, Tim; Kaiser, Kate; and Simon, Judith (2006). IT Workforce Trends: Implications For IS Programs. Communications of the Association for Information Systems, 17(1), 1147-1170.

2. ACM and AIS (2010). IS 2010: Curriculum Guidelines for Undergraduate Degree Programs in Information Systems. Available at http://www.acm.org/education/curricula

3. Anderson-Cruz, Helen and Gretchen N. Vik. (2007). Using Project-Based Learning to Connect Theory to Practice in Teaching Accounting Communication, Proceedings of the 2007 Association for Business Communication Annual Convention

4. Borzak, L. (1981). Field study: A Source Book for Experiential Learning. Beverly Hills: Sage.

5. Bullen, Christine V.; Abraham, Thomas; Gallagher, Kevin; Simon, Judith C.; and Zwieg, Phil (2009). IT Workforce Trends: Implications for Curriculum and Hiring. Communications of the Association for Information Systems, 24(9), 129-140.

6. Firth, David; King, John; Koch, Hope; Looney, Clayton Arlen; Pavlou, Paul; and Trauth, Eileen M. (2011). Addressing the Credibility Crisis in IS. Communications of the Association for Information Systems, 28(13), 200-212.

7. Future of Computing in Education Summit (2009). Association for Computing Machinery. Available at $\mathrm{http} / / / \mathrm{www}$.acm.org/education/future-of-computing-education-summit

8. Ginzberg, Michael J. (2012). A Business Dean's Perspective on the IS Field. The DATA BASE for Advances in Information Systems, 43(2).

9. Granger, Mary J.; Dick, Geoffrey; Luftman, Jerry; Van Slyke, Craig; and Watson, Richard T. (2007). Information Systems Enrollments: Can They Be Increased? Communications of the Association for Information Systems, 20 (41). 649- 659.

10. Gray, Paul. (2012). The Other?. The DATA BASE for Advances in Information Systems, 43(2), 26-32.

11. Houle, C. (1980). Continuing Learning in the Professions. San Francisco, CA: Jossey-Bass Publishers.

12. Koch, Hope; Van Slyke, Craig; Watson, Rick; Wells, John; and Wilson, Rick (2010). Best Practices for Increasing IS Enrollment: A Program Perspective. Communications of the Association for Information Systems, 26(22), 478-492.

13. Kolb, D. A. (1984). Experiential Learning: Experience as the Source of Learning and Development. Englewood Cliffs, N.J.: Prentice-Hall, Inc.

14. Ramos-Torres, A. (2013). Current IS program challenges and proposed strategies to address them. Issues in Information Systems, 14(2), 101-108.

15. Todd, Peter. (2012). What are They Thinking...A View of the IS Field "from the Dean's Office". The DATA BASE for Advances in Information Systems 43(2), 20-25.

16. Zweben, Stuart (2011). Computing Degree and Enrollment Trends, Computing Research Association, Retrieved from http://cra.org 